\title{
Factors affecting immunoglobulin concentration in colostrum of healthy Holstein cows immediately after delivery ${ }^{1}$
}

\author{
Viviani Gomes ${ }^{2 *}$, Karina Medici Madureira ${ }^{3}$, Sérgio Soriano ${ }^{4}$, Alice Maria Melville \\ Paiva Della Libera ${ }^{2}$, Maiara Garcia Blagitz ${ }^{3}$ and Fernando José Benesi ${ }^{2}$
}

\begin{abstract}
Gomes V., Madureira K.M., Soriano S., Della Libera A.M.M.P., Blagitz M.G. \& Benesi F.J. 2011. Factors affecting immunoglobulin concentration in colostrum of healthy Holstein cows immediately after delivery. Pesquisa Veterinária Brasileira 31(Supl.1):5356. Departamento de Clínica Médica, Faculdade de Medicina Veterinária e Zootecnia, Universidade de São Paulo, Av. Prof. Dr. Orlando Marques de Paiva 87, Cidade Universitária, São Paulo, SP 05508-270, Brazil. E-mail: viviani.gomes@usp.br

This study analyzed the influence of the number of milkings, number of births, and udder quarter in immunoglobulin (Ig) concentration in the colostrum of healthy Holstein cows. It was collected two samples of colostrum by manual milking, getting the first jets to completion of bacteriological examination and immunoglobulin levels by radial immunodiffusion test in agar gel. Positive samples for bacteriological examination were excluded from this investigation. Medians of immunoglobulin's G, A and M in the colostrum collected before the first and second milking were respectively 9,200 and $6,400 \mathrm{mg} / \mathrm{dL}(\mathrm{p}=0.0029)$; 400 and $200 \mathrm{mg} / \mathrm{dL}(\mathrm{p}=0.0018) ; 800$ and $400 \mathrm{mg} / \mathrm{dL}$ ( $\mathrm{p}=0.0001)$. Median immunoglobulin concentration in animals that calved once, twice or three times or in cows that calved 4 to 6 times were 6,$400 ; 6,400 ; 3,200$ and $11,200 \mathrm{mg} / \mathrm{dL} \mathrm{IgG;} \mathrm{100,} \mathrm{200,} 100$ and $800 \mathrm{mg} / \mathrm{dL}$ IgA ; and 400, 400, 100 and $800 \mathrm{mg} / \mathrm{dL}$ IgM, respectively. Concentrations of IgG, IgA and IgM were greater in animals that calved more than 4 times $(\mathrm{p}<0.05)$. Medians of IgG, IgA and IgM in the right fore quarter (RF), right hind quarter (RH), left fore quarter (LF) and left hind quarter (LH) were, respectively, 7,800;6,400; 7,800 and 6,400mg/dL; 200, 200, 200 and $200 \mathrm{mg} / \mathrm{dL}$; and 400,400, 400 and $400 \mathrm{mg} / \mathrm{dL}$. Ig concentrations in the colostrum of Holstein cows were influenced by the number of milkings after delivery and number of lactations. These variations may be considered risk factors to passive immunity transfer to newborn calves, predisposing them to diseases and causing economic losses to dairy production.
\end{abstract}

INDEXS TERMS: Immunoglobulins, colostrum, milkings, udder quarter.

RESUMO.- [Fatores que afetam o nível de imunoglobulina no colostro de vacas Holandesas sadias imediatamente após o parto.] A pesquisa avaliou a influência do número de ordenhas, número de parições e quarto mamário na concentração de imunoglobulinas (Ig) do colostro de vacas hígidas da raça Holandesa. Foram colhidas duas amostras de colostro por ordenha manual, obtendo-se os

\footnotetext{
${ }^{1}$ Received on April 5, 2011.

Accepted for publication on November 26, 2011.

${ }^{2}$ Departamento de Clinica Médica, Faculdade de Medicina Veterinária e Zootecnia (FMVZ), Universidade de São Paulo (USP), Av. Prof. Dr. Orlando Marques de Paiva 87, Cidade Universitária, São Paulo, SP 05508-270, Brazil. *Corresponding author: viviani.gomes@usp.br

${ }^{3} \mathrm{PhD}$ student at Departamento de Clinica Médica, FMVZ-USP, São Paulo, SP.

${ }^{4}$ Veterinarian at Colorado Farm, Araras, SP.
}

primeiros jatos para a realização do exame bacteriológico e determinação dos níveis de imunoglobulinas pelo teste de imunodifusão em gel de ágar. As amostras positivas ao exame bacteriológico foram eliminadas desta investigação. Os valores medianos obtidos para a concentração de imunoglobulinas das classes G, A e M do colostro colhido antes da primeira e segunda ordenha foram, respectivamente de 9.200 e $6.400 \mathrm{mg} / \mathrm{dL}(\mathrm{p}=0,0029) ; 400$ e $200 \mathrm{mg} /$ $\mathrm{dL}(\mathrm{p}=0,0018) ; 800$ e $400 \mathrm{mg} / \mathrm{dL}(\mathrm{p}=0,0001)$, respectivamente. Os valores medianos da concentração de imunglobulinas, nos animais com apenas 1 parto, 2, 3 ou nas vacas com 4 a 6 partos foram de $6.400,6.400,3.200$ e $11.200 \mathrm{mg} /$ dL para a IgG; 100, 200, 100 e $800 \mathrm{mg} / \mathrm{dL}$ para a IgA; e 400, 400,100 e $800 \mathrm{mg} / \mathrm{dL}$ para a IgM, respectivamente. As concentrações de IgG, IgA e IgM foram superiores nos animais 
com mais de 4 partos $(p<0,05)$. Os valores medianos de IgG, IgA e IgM obtidos nos quartos mamários anterior direito (AD), posterior direito (PD), anterior esquerdo (AE) e posterior esquerdo (PE) foram respectivamente 7.800, 6.400, $7.800,6.400 \mathrm{mg} / \mathrm{dL} ; 200,200,200,200 \mathrm{mg} / \mathrm{dL} ;$ e 400,400 , 400 e $400 \mathrm{mg} / \mathrm{dL}$, não observando-se diferenças estatísticas $(p>0,05)$ entre os quartos mamários. Os teores de Igs do colostro de vacas Holandesas sofrem influência do número de ordenhas pós-parto e número de lactações. Estas variações podem ser consideradas fatores de risco associados à falha na transferência de imunidade passiva em bezerros neonatos, predispondo-os às doenças e ocasionando perdas produtivas á pecuária.

TERMOS DE INDEXAÇÃO: Imunoglobulinas, colostro, ordenhas, quarto mamário.

\section{INTRODUCTION}

Due to its high nutritive and immunological value, bovine milk and colostrum are used to feed humans and animals (Cross \& Gill 2000, He et al. 2001). Colostrum has an extremely important role in local and systemic immunity transfer in ruminants because the synepitheliochorial placenta of bovines prevents maternal antibodies from reaching the fetus during pregnancy (Salmon 1999). Intake of colostrum may prevent a series of diseases in the first months after birth, such as diarrhea, bronchopneumonia, umbilical disorders and septicemia (Radostits et al. 2007).

Failure of passive immunity transfer (FPIT) immediately after birth is related both to characteristics of the mother (deficient production or low quality of the colostrum) and of the newborn calves (inadequate intake due to insufficient ingestion or intestinal absorption) (Gay \& Besser 1991). National and international literatures recommend the intake of four liters of colostrum in the first 12 hours after delivery for adequate passive immunity transfer (Gay \& Besser 1991, Morin et al. 1997, Borges et al. 2001, Feitosa et al. 2003, Radostits et al. 2007).

Bovine colostrum is rich in immunoglobulins (Ig), especially IgG1. They are transferred from blood to the udder during colostrogenesis (Lascelles 1979, Larson et al. 1980, Barrington \& Parrish 2001). However, Ig concentration in colostrum is still affected by several other factors, such as breed, number of milkings after delivery, number of lactations, length of the dry period, season when calving took place and body condition score (Oyeniyi \& Hunter 1978, Muller \& Ellinger 1981, Pritchett et al. 1991, Shearer et al. 1992, Quigley et al. 1994, Filteau et al. 2003, Jaster 2005, Kehoe et al. 2007).

Colostrometer determination of Ig concentrations in Jersey cows before the first milking was reported by Quigley et al. (1994): 6,580mg/dL IgG, 240mg/dL IgM and $170 \mathrm{mg} / \mathrm{dL}$ IgA.

Oyeniyi \& Hunter (1978) evaluated immunoglobulin G concentration in the colostrum of Holstein cows during the first three milkings postpartum, and reported means e of $3,240 \mathrm{mg} / \mathrm{dL}$ and $2,540 \mathrm{mg} / \mathrm{dL}$ in colostrum samples collected in the first and second milking, respectively.

Pritchett et al. (1991) reported mean values of $4,800 \mathrm{mg} /$ dL IgG1 in the colostrum of Holstein cows and a gradual in- crease to values ranging from 4,200 to $5,500 \mathrm{mg} / \mathrm{dL}$ IgG1 in cows from the first to the fifth lactation.

Kehoe et al. (2007) reported values equal to $3,500 \mathrm{mg} /$ $\mathrm{dL}$ IgG1, $600 \mathrm{mg} / \mathrm{dL}$ IgG2, $170 \mathrm{mg} / \mathrm{dL}$ IgA and $430 \mathrm{mg} / \mathrm{dL}$ IgM in the colostrum of Holstein cows.

Vaz et al. (2004) evaluated the quality of colostrum in terms of Ig concentration in Holstein and mixed breed cows by means of zinc sulfate turbidity test. Immunoglobulin concentration in bovine colostrum ranged from 2,719 to $8,850 \mathrm{mg} / \mathrm{dL}$.

Soares Filho et al. (2001) studied immunoglobulin G concentration in bovine colostrum collected in the first milking of Holstein cows using radial immunodiffusion and reported values of $1540 \mathrm{mg} / \mathrm{dL}$.

Although some Brazilian studies analyzed immunoglobulin concentration in bovine colostrum (Soares Filho et al. 2001, Vaz et al. 2004), physiological factors affecting these concentrations have not been discussed yet. Due to the importance of immunological quality of bovine colostrum in passive immunity transfer to newborn calves, the objective of this study was to evaluate the influence of the number of mikings, number of deliveries, and udder quarter in Ig concentration in the colostrum of Holstein cows.

\section{MATERIALS AND METHODS}

Colostrum samples were collected from udder quarters of 53 Holstein (212 samples) cows raised in intensive conditions in four farms located in the countryside of Sao Paulo, Brazil. Cows used in this study had a dry period of 2 months before their calving date. After that, they were placed in maternity pens at 245 to 250 days of pregnancy, and were vaccinated against neonatal diarrhea, environmental mastitis, infectious bovine keratoconjunctivitis and clostridiosis.

Immediately after calving, cows were separated from the newborn calves in order to prevent them from sucking colostrum directly from their mothers. Cows were sent to the milking parlor where colostrum samples were collected before the first and second milking, at most 12 hours after calving.

Samples were collected after teats were cleaned and disinfected with water and hypochlorite, dried with paper towels and teat orifices were disinfected with $70 \%$ ethanol. Two aliquots were collected from each mammary gland by milking and obtaining the first streams of colostrum. The first aliquot $(20 \mathrm{~mL})$ was collected in a sterile Falcon tube for the Ig assay. The second aliquot was collected in sterile glass tubes for bacteriological examination.

In the laboratory, the first aliquot of colostrum was centrifuged at 3,600 rpm for one hour. After centrifugation, colostrum was separated in three phases: an upper fat layer, a liquid portion (supernatant) and the cell button. The supernatant was separated and stored at $-20^{\circ} \mathrm{C}$ in $3-\mathrm{mL}$ sterile plastic microtubes inside a safety cabinet.

Concentrations of immunoglobulins G, M and A were determined by means of simple radial immunodiffusion using a commercial kit (Mancini et al. 1965). Agar plates incorporated with anti-bovine immunoglobulin G, M and A were used.

Three $\mathrm{mL}$ of colostrum serum were transferred with a pipette to specific plates for the IgG, IgA and IgM quantitative assay. Prepared plates were incubated for 18 to 24 hours at room temperature. Immunoglobulin quantification was carried out by comparing the intensity of the reaction observed in the samples with an immunoglobulin standard at a predetermined concentration: Radial Imunodiffusion (RID) Kits, Catalog no 240-30 isotype IgG, 
246-60 isotype IgA, 246-60 isotype IgM, VMRD ${ }^{\circledR}$. Samples that showed reactions more intense than the sensitivity threshold of the method were diluted in buffered saline (1:1) and evaluated again. Values obtained in the analyses were multiplied by the final dilution used.

A second aliquot $(10 \mu \mathrm{L})$ of colostrum was placed in a Petri dish containing $5 \%$ sheep blood agar and incubated for 72 hours. Samples positive in bacteriological analysis were not used in the study.

In order to determine the effect of the number of milkings on Ig concentration, samples were divided into two groups, those collected before the first milking after delivery and those collected before the second milking. To determine the influence of the number of deliveries in Ig concentration, samples were divided into four groups: animals that calved once, twice, three times and four to six times; and to assess the influence of the udder quarter in Ig concentration in bovine colostrum, samples were divided into four groups: right fore quarter (RF), right hind quarter (RH), left fore quarter (LF), and left hind quarter (RH).

Results obtained for the variables studied were tested for normality by Kolmogorov-Smirnov test and showed non-parametric distribution. Therefore, medians were calculated for each parameter. Differences between Ig concentrations according to the number of milkings after delivery was determined by Mann-Whitney test. Results obtained for the number of deliveries and udder quarters was determined by means of Kruskal-Wallis and Dunn tests (Sampaio 1998).

\section{RESULTS AND DISCUSSION}

Medians of imunoglobulin G, A and M in the colostrum collected before the first and second milking were 9,200 and $6,400 \mathrm{mg} / \mathrm{dL}(\mathrm{p}=0.0029) ; 400$ and $200 \mathrm{mg} / \mathrm{dL}(\mathrm{p}=0.0018) ;$ 800 and $400 \mathrm{mg} / \mathrm{dL}(\mathrm{p}=0.0001)$, respectively (Table 1 ). If Ig concentration before the first milking were multiplied by the amount of colostrum (four liters) offered to newborn calves in the first twelve hours of life, as recommended by Gay\& Besser (1991) and Morin et al. (1997) for dairy cows, these newborns would ingest a total of $368 \mathrm{~g}$ of IgG, $16 \mathrm{~g}$ of $\operatorname{IgA}$ and $32 \mathrm{~g}$ of IgM. These values are far greater than the $100 \mathrm{~g}$ immunoglobulin recommended by Radostits et al. (2007) to protect calves during their neonatal period.

Immunoglobulin concentrations in first milking colostrum $(9,200 \mathrm{mg} / \mathrm{dL} \mathrm{IgG;} 400 \mathrm{mg} / \mathrm{dLIgA}$; and $800 \mathrm{mg} / \mathrm{dL}$ IgM) were greater than $4,820 \mathrm{mg} / \mathrm{dL}$ IgG1 reported by Pritchett et al. (1991), 6,730mg/dL IgG reported by Quigley et al. (1994), and 3,496mg/dL IgG1 reported by Kehoe et al. (2007). These differences may be related to breed, nutritional and sanitary management of the herd, and the technique used in the Ig assay, once Quigley et al. (1994) and Kehoe et al. (2007) used a colostrometer for indirect

Table 1. Median of immunoglobulin concentration in the colostrum of Holstein cows according to the number of milking after calving

\begin{tabular}{lccc}
\hline Moment of milking & $\operatorname{IgG}(\mathrm{mg} / \mathrm{dL})$ & $\operatorname{IgA}(\mathrm{mg} / \mathrm{dL})$ & $\operatorname{IgM}(\mathrm{mg} / \mathrm{dL})$ \\
\hline $1^{\text {st }}$ milking* $^{*}$ & $9,200^{\mathrm{a}}$ & $400^{\mathrm{a}}$ & $800^{\mathrm{a}}$ \\
$2^{\text {nd }}$ milking* & $6,400^{\mathrm{b}}$ & $200^{\mathrm{b}}$ & $400^{\mathrm{b}}$ \\
P value & $\mathrm{P}=0.0029$ & $\mathrm{P}=0.0018$ & $\mathrm{P}=0.0001$
\end{tabular}

a,b Different lower case letters in the same columm show statistically differences between them $(\mathrm{p}<0.05)$.

* Number of samples tested: 79 samples in the $1^{\text {st }}$ milking and $1^{\text {st }}$ milking in the $2^{\text {nd }}$ milking. quantification of Ig levels in colostrum. However, pre-delivery vaccination of cows may have been the main factor influencing Ig concentrations, which were greater than the ones reported by these other authors.

Vaz et al. (2004) evaluated colostrum samples collected from Holstein cows raised in the state of Minas Gerais and observed total immunoglobulin levels $(2,719-8,850 \mathrm{mg} / \mathrm{dL}$ Igs) that were lower than those reported here $(9,200 \mathrm{mg} /$ $\mathrm{dL} I g G, 400 \mathrm{mg} / \mathrm{dL} \operatorname{IgA}$ and $800 \mathrm{mg} / \mathrm{dL}$ IgM). However, these authors did not describe the sanitary status of the cows. Besides, antibody concentrations were determined by an indirect qualitative technique (zinc sulfate turbidity test) and not by radial immunodiffusion, the method chosen in this study.

Soares Filho et al. (2001) analyzed IgG concentation in the colostrum of Holstein cows in the state of Minas Gerais and observed values of $15,000 \mathrm{mg} / \mathrm{dL}$ IgG that was less than reported here $(9,200 \mathrm{mg} / \mathrm{dL} \mathrm{IgG})$.

Oyeniyi \& Hunter (1978), in the analysis of colostrum samples collected within three milkings after delivery, founded lower IgG concentrations of 2,900mg/dL, 2,350mg/dL and $1430 \mathrm{mg} / \mathrm{dL}$, respectively, in the first, second and third milking) than the ones reported here $(9,200$ and $6,400 \mathrm{mg} /$ $\mathrm{dL}$, respectively, first and second milking). However, a decrease in Ig concentration from the first $(2,900 \mathrm{mg} / \mathrm{dL})$ to the second $(2,350 \mathrm{mg} / \mathrm{dL})$ milking after delivery was observed in the present study.

Medians of IgG, IgA and IgM in animals that calved once, twice or three times or in cows that calved 4 to 6 times were, respectively, 6,400; 6,400; 3,200; and $11,200 \mathrm{mg} /$ $\mathrm{dL} ; 100,200,100$ and $800 \mathrm{mg} / \mathrm{dL}$; and 400, 400, 100 and $800 \mathrm{mg} / \mathrm{dL}$. Immunoglobulin $\mathrm{G}, \mathrm{A}$ and $\mathrm{M}$ concentrations were greater in animals that had calved more than 4 times $(\mathrm{p}<0.05)$ (Table 2).

\section{Table 2. Median of immunoglobulin concentration in the colostrum of Holstein cows according to the number of deliveries}

\begin{tabular}{lcccc}
\hline Number of deliveries & $\begin{array}{c}\text { Number of } \\
\text { samples (n) }\end{array}$ & $\begin{array}{c}\text { IgG (mg/ } \\
\mathrm{dL})\end{array}$ & $\begin{array}{c}\text { IgA (mg/ } \\
\mathrm{dL})\end{array}$ & $\begin{array}{c}\text { IgM (mg/ } \\
\mathrm{dL})\end{array}$ \\
\hline 1 delivery $^{*}$ & 32 & $6,400^{\mathrm{d}}$ & $100^{\mathrm{bc}}$ & $400^{\mathrm{ac}}$ \\
2 deliveries $^{*}$ & 72 & $6,400^{\mathrm{bd}}$ & $200^{\mathrm{ab}}$ & $400^{\mathrm{a}}$ \\
3 deliveries $^{*}$ & 16 & $3,200^{\mathrm{cd}}$ & $100^{\mathrm{c}}$ & $100^{\mathrm{bc}}$ \\
4 to 6 deliveries $^{*}$ & 20 & $11,200^{\text {ad }}$ & $800^{\mathrm{a}}$ & $800^{\mathrm{a}}$ \\
\hline
\end{tabular}

$\overline{a, b, c, d}$ Different lower case letters in the same column show statistical differences between them $(\mathrm{p}<0.05)$.

Pritchett etal. (1991) reported mean values of $4,800 \mathrm{mg} /$ dL IgG1 in the colostrum of Holstein cows and a gradual increase to values ranging from 4,200 to $5,500 \mathrm{mg} / \mathrm{dL}$ IgG1 in cows between the first and fifth lactation. This oscillation was also observed in IgG in the present study, "I.E.", older cows showed greater IgG concentrations $(11,200 \mathrm{mg} / \mathrm{dL})$ than younger animals $(6,400 \mathrm{mg} / \mathrm{dL})$.

Medians of Ig concentrations according to the udder quarter were 7,$800 ; 6,400 ; 7,800 ; 6,400 \mathrm{mg} / \mathrm{dL} \mathrm{Ig} \mathrm{G;} \mathrm{200,}$ $200,200,200 \mathrm{mg} / \mathrm{dL}$ IgA; and $400,400,400$ e $400 \mathrm{mg} / \mathrm{dL}$ IgM, respectively, for RF, RH, LF, and LH. There were no statistical differences in Ig concentrations in colostrum according to the udder quarter $(p>0.05)$ (Table 3$)$. 
Table 3. Median of immunoglobulin concentration in the colostrum of Holstein cows according to udder quarter

\begin{tabular}{lcccc}
\hline \multicolumn{1}{c}{ Udder quarter } & $\begin{array}{c}\text { Number of } \\
\text { samples (n) }\end{array}$ & $\begin{array}{c}\text { IgG } \\
(\mathrm{mg} / \mathrm{dL})\end{array}$ & $\begin{array}{c}\text { IgA } \\
(\mathrm{mg} / \mathrm{dL})\end{array}$ & $\begin{array}{c}\text { IgM } \\
(\mathrm{mg} / \mathrm{dL})\end{array}$ \\
\hline Right fore quarter (RF) & 34 & 7,800 & 200 & 400 \\
Right hind quarter (RH) & 34 & 6,400 & 200 & 400 \\
Left fore quarter (LF) & 34 & 7,800 & 200 & 400 \\
Left hind quarter (LH) & 34 & 6,400 & 200 & 400 \\
\hline
\end{tabular}

Significance differences were not observed ( $p>0.05$ ).

Although no studies in the literature evaluated the influence of the quarter in Ig concentration of colostrum, this kind of information is important in the development of studies for beef cattle raised under extensive conditions, once post-calving monitoring and separation of the newborn calf and the mother to prevent colostrum intake is difficult. Therefore, based on this finding, it is possible to isolate only one teat to collect colostrum in the first milking, once this quarter will show the same Ig profile of the other three quarters.

Approved by the Bioethics Committee of the Faculdade de Medicina Veterinária e Zootecnia, Universidade de São Paulo, Protocol Number 1.273/2008.

\section{CONCLUSION}

Immunoglobulin concentrations in the colostrum of Holstein cows were influenced by the number of milking after delivery and the number of lactations. These variations may reduce the immunological quality of colostrum, interfering with passive immunity transfer to newborn calves, either if they suck directly from the cow or if they are fed with stored colostrum from colostrum banks.

\section{REFERENCES}

Barrington G.M. \& Parish S.M. 2001. Bovine neonatal immnunology. Vet. Clin. North Am., Food Anim. Pract. 17(3):463-477.

Borges A.S., Feitosa F.L.F., Benesi F.J., Birgel E.H. \& Mendes L.C.N. 2001. Influência da forma de administração e da quantidade fornecida de colostro sobre a concentração de proteina total e de suas frações eletroforéticas no soro sanguíneo de bezerros da raça Holandesa. Arq. Bras. Med. Vet. Zootec. 53(5):629-634.

Cross M.L. \& Gill H.S. 2000. Immunomodulatory properties of milk. Brit. J. Nutr. 84(Suppl.1):S81-S89.

Feitosa F.L., Borges A.S., Benesi F.J., Birgel E.H., Mendes L.C.M. \& Peiro J.R. 2003. Concentração de imunoglobulinas $\mathrm{G}$ e $\mathrm{M}$ no soro sanguíneo de bezerros da raça Holandesa até os 90 dias de vida. Braz. J. Vet. Res. Anim. Sci. 40(Suppl.1):26-31.
Filteau V., Bouchard E., Fecteau G., Dutil L. \& Tremblay D. 2003. Health status and risk factors associated with failure of passive transfer of immunity in newborn beef calves in Québec. Can. Vet. J. 44:907-913.

Gay C.C. \& Besser T. E. 1991. Colostrum and feeding management of dairy calf during the first two day of life, p.243-247. In: Naylor J.M. \& Ralston S.L. (Eds), Large Animal Clinical Nutrition. Mosby, St Louis.

He F., Tuomola E., Arvilommi H. \& Salminen S. 2001. Modulation of human humoral immune response through orally administered bovine colostrums. FEMS Immunology and Medical Microbiology 31:93-96.

Jaster E.H. 2005. Evaluation of quality, quantity, and timing of colostrums feeding on immunoglobulin G1 absorption in Jersey calves. J. Dairy Sci. 88:296-302.

Kehoe S., Jayarao B.M. \& Heinrichs A.J. 2007. A survey of bovine colostrums composition and colostrum management practices on Pennsylvania dairy farms. J. Dairy Sci. 90:4108-4116.

Larson B.L., Leary, H.L. \& Devery J.E. 1980. Immunoglobulin production by the mammary gland. J. Dairy Sci. 63:665-671.

Lascelles A.K. 1979. The immune system of the ruminant mammary gland and its role in the control of mastitis. J. Dairy Sci. 62:154-167.

Mancini G., Carbonara A.O. \& Heremans J.F. 1965. Immunochemical quantitation of antigens by simple radial immunodiffusion. Immunochemistry 2:235-254.

Morin D.E., Mccoy G.C. \& Hurley W.L. 1997. Effects of quality, quantity and timing feeding and addition of a dried colostrums supplement on immunoglobulin G1 absorption in Holstein bull calves. J. Dairy Sci. 80:747-753.

Muller L.D. \& Ellinger D.K. 1981. Colostral immunoglobulin concentration amomg breeds of dairy cattle. J. Dairy Sci. 64:1727-1730.

Oyeniyi O.O. \& Hunter A.G. 1978. Colostral constituents including immunoglobulins in the first three milkings postpartum. J. Dairy Sci. 61:44-48.

Pritchett L.C., Gay C.C. Besser T.E. \& Hancock D.D. 1991. Management and production factors influencing immunoglobulin G1 concentration in colostrums from Holstein cows. J. Dairy Sci. 74:2336-2341.

Quigley J.D., Martin K.R., Dowlen H.H., Wallis L.B. \& Lama K. 1994. Immunoglobulin concentration, specific gravity, and nitrogen fractions of colostrums from Jersey cattle. J. Dairy Sci. 77(1):264-269.

Radostits O.M., Gay C.C., Hinchcliff K.W. \& Constable P.D. 2007. Veterinary medicine: A textbook of the diseases of cattle, horses, sheep, pigs, and goats. $10^{\text {th }}$ ed. Saunders Elsevier, Philadelphia.

Salmon H. 1999. The mammary gland and newborn calves mucosal immunity. Vet. Immunol. Immunopathol. 72:143-155.

Sampaio I.B. 1998. Estatística Aplicada à Experimentação Animal. Universidade Federal de Minas Gerais, Belo Horizonte. 221p.

Shearer J., Mohammed H.O., Brenneman J.S. \& Tran T.Q. 1992. Factors associated with concentrations of immunoglobulins in colostrum at the first Milking post-calving. Prev. Vet. Med. 14(1/2):143-154.

Soares Filho P.M., Belém P.A.D., Ribeiro-Júnior J.I. \& Salcedo J.H.P. 2001. Concentrações de imunoglobulinas $\mathrm{G}$ em colostro de vacas mestiças Holandês-Zebu. Ciência Rural 31(6):1033-1035.

Vaz A.K., Furtado A.C., Mrca A. \& Paterno M.R. 2004. Qualidade do colostro bovino e transferência de imunidade aos bezerros recém-nascidos na região leste de Lages , SC. Revta Ciênc. Agrovet. 3(2):116-120. 